\title{
Understanding the Eminence of Retailers towards Paints with respect to Jammu
}

\author{
Dr.Rahul Hakhu \\ Associate Professor, AIT-USB, Chandigarh University, \\ Gharuan, Punjab, India
}

\begin{abstract}
Indian paint industry is very proficient and with huge demand creates an optimistic position in the market. A survey analysis has been undertaken for 50 retailers of Jammu in India to understand their standing towards Paints. The results highlight that Asian Paints is the most supreme paint and furthermore Brand Loyalty is the highest factor for purchasing decision of paints by the retailers in Jammu. Similarly when retailers make their purchase decision they get influenced by several major factors such as Demographic, Social, Cultural etc. It is also found that $88 \%$ retailers in Jammu are in conformity with their perception towards paints for pleasing the condition.
\end{abstract}

Keywords: Paints, Jammu, Retailer

\section{INTRODUCTION}

In the present competitive world if any business organization has to survive it needs to keep an eye on various forces operating in the market. More over competitors constantly try to win over others. In this scenario, every business organization needs to monitor the changes taking place in the market so that they are not wedged. Company's ability to maintain satisfying customer relationships requires an understanding of retailer buying behaviour. This refers to the buying behaviour of consumers who purchase products or services for their personal or household use. Consumers have limited time, energy and financial resources. Within the available resources, they make purchase and consumption

choices as they wish. Consumers purchasing decisions take place over a period of time. The overall goal during this decision process is to evaluate various alternatives and choose the product that satisfies the retailer in an optimal way.

India is an attractive market for paints as the per capita consumption is low as compared to developed nations, thereby offering huge growth potential. The consumer's degree of interest in a product and the importance he/she places on this product determines the consumer's level of involvement. When customer comes for the purpose of purchasing an Paints, they consider many things in their mind such as brand reliability, applications, cost etc. Because they know that they are purchasing to apply on and they are not going to purchase in frequently bases. Paints are the most adaptable bonding agents available in the market, which remained unaffected by the recent global slowdown due to their application in a wide variety of end user industries. Usage of paints in the country is witnessing an increase in composite, usage, etc. Moreover, the market is witnessing increase in its competition, $\mathrm{R} \& \mathrm{D}$ operations and new players entering the market. As a result, the paints market size is expected to grow, both in volume as well as value terms. The paint market, in terms of value and volume, is estimated by considering the current and future projections according to the economic and industrial outlook. In addition, product innovation is increasingly becoming vital in Indian paint industry due to its fragmented structure and stiff market competition. 


\section{REVIEW OF LITERATURE}

According to Rowley (1997) consumer buying process offers two valuable perspectives: the decisionmaking process connected with consumer buying and the factors which influence the buying process. According to Priya Soni (2010) that there is prevailing high competition among various brands in India. Raghavan (2006) says that the Indian paint industry has completed its 100 years of manufacturing. Pallavi Kumari (2012) says that the way Indian consumers are spending their money on a variety of items has changed in lately. According to Akhilesh Chandra Pandey (2009) Paint companies are performing at their best this moment.

\section{RESEARCH METHODOLOGY}

Objectives of the Study

$>$ To find the most supreme paints by the retailers in Jammu.

$>$ To find the factors for purchasing decision of an paints by a retailer in Jammu.

To find the perception of retailers in Jammu towards paints for pleasing the condition.

Sample unit: Jammu

Sample Size: A random sample of 50 Retailers has been drawn.

Data Collection: The data collection had been done by interviewing respondents through structured questionnaire

\section{ANALYSIS AND INTERPRETATION}

Most supreme paints by a retailer in Jammu.

\begin{tabular}{|lllll|}
\hline $\begin{array}{l}\text { Nerolac } \\
\text { Paints }\end{array}$ & $\begin{array}{l}\text { Shalimar } \\
\text { Paints }\end{array}$ & $\begin{array}{l}\text { Berger } \\
\text { Paints }\end{array}$ & $\begin{array}{l}\text { Asian } \\
\text { Paints }\end{array}$ & Others \\
\hline $\mathbf{1 8 \%}$ & $12 \%$ & $26 \%$ & $36 \%$ & $8 \%$ \\
\hline
\end{tabular}

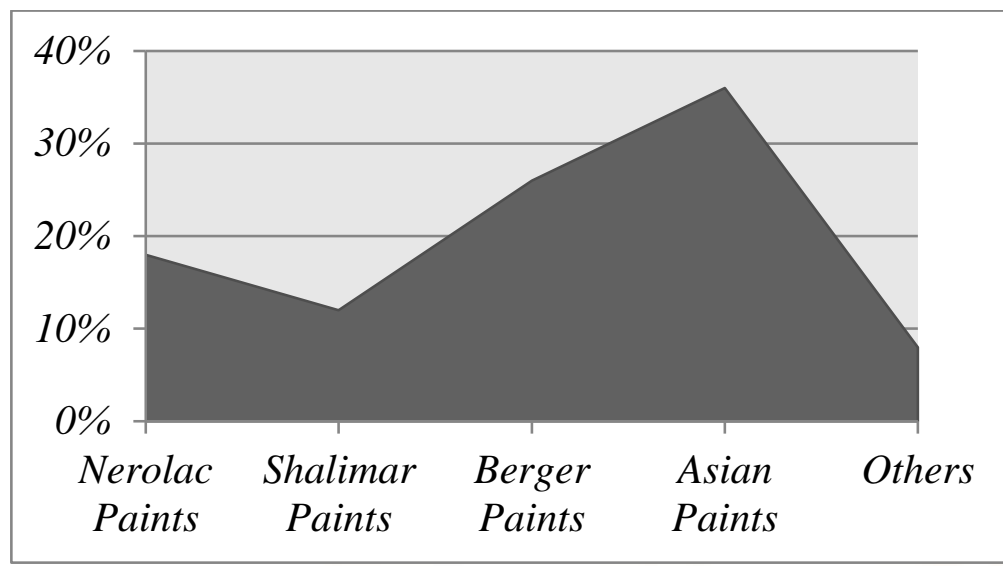

Figure 1

\section{Interpretation:}

Out of 50 retailers in Jammu, Asian Paints with 36\% is the most supreme paint followed by Berger Paints with $26 \%$.

Factors for purchasing decision of paints by a retailer in Jammu

\begin{tabular}{|l|l|l|l|}
\hline Profit & $\begin{array}{l}\text { Market } \\
\text { Demand }\end{array}$ & $\begin{array}{l}\text { Brand } \\
\text { Loyalty }\end{array}$ & Distributor \\
\hline $\mathbf{3 2 \%}$ & $18 \%$ & $38 \%$ & $12 \%$ \\
\hline
\end{tabular}

\section{Table 2}

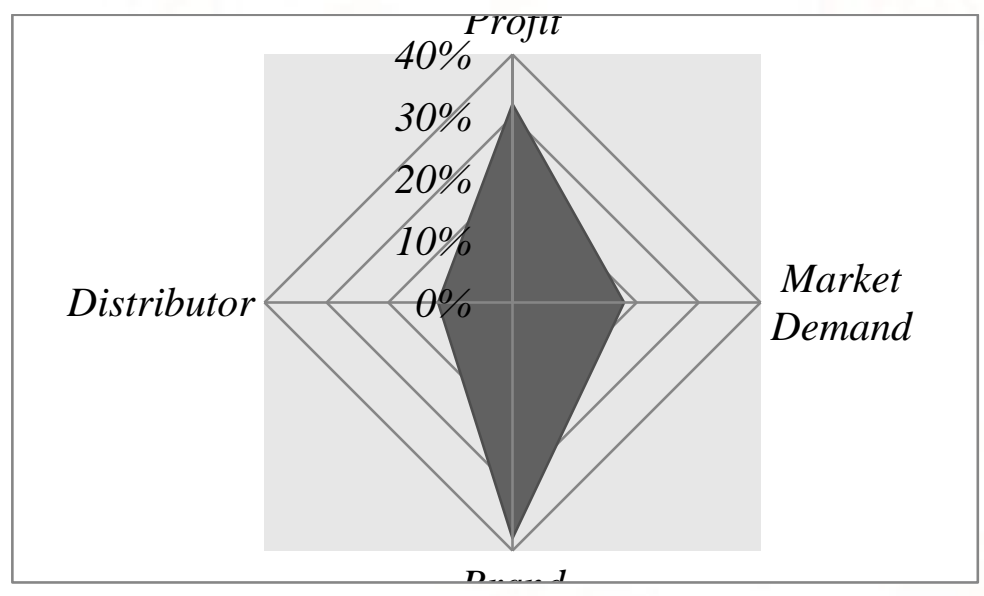

Figure 2

\section{Interpretation:}

Out of 50 retailers in Jammu, Brand Loyalty with $38 \%$ is the highest factor for purchasing decision of paints followed by Market Demand with $18 \%$. 
Perception of retailers in Jammu towards paint for pleasing the condition.

\begin{tabular}{|l|l|l|l|l|}
\hline $\begin{array}{l}\text { Strongly } \\
\text { Disagree }\end{array}$ & Disagree & $\begin{array}{l}\text { Moderately } \\
\text { Agree }\end{array}$ & Agree & $\begin{array}{l}\text { Strongly } \\
\text { Agree }\end{array}$ \\
\hline $\mathbf{2 \%}$ & $10 \%$ & $58 \%$ & $24 \%$ & $6 \%$ \\
\hline
\end{tabular}

Table 3

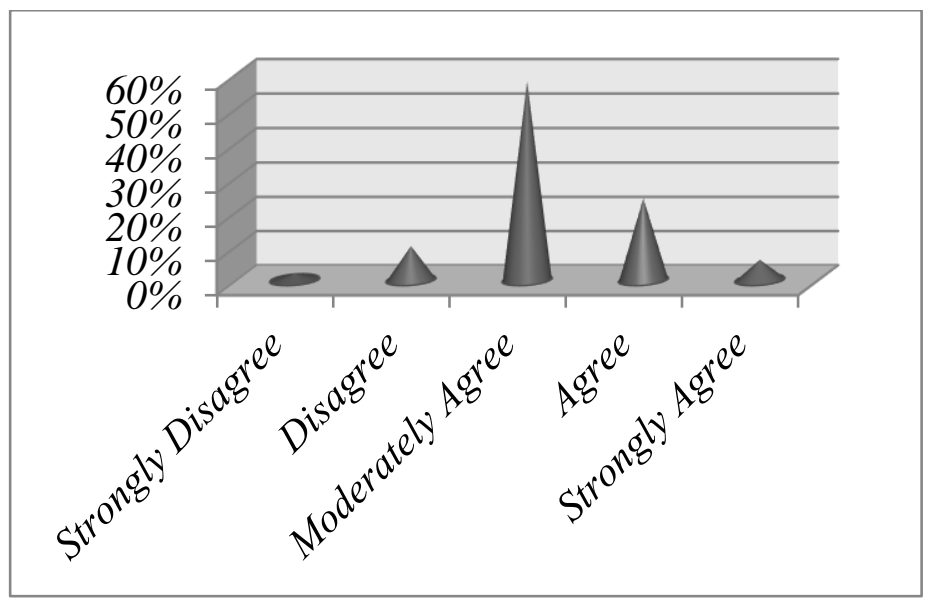

Figure 3

\section{Interpretation:}

Out of 50 retailers in Jammu, 24\% Agree and 58\% moderately agree with their perception towards paint for pleasing the condition.

\section{CONCLUSION}

This study helps to understand the retailer behaviour towards purchasing Paint in Jammu. It also opens the various factors which can affect the purchase decision. This study finds the most supreme paints and also finds the factors for purchasing decision of paints by a retailer in Jammu. Furthermore it finds the perception of retailers in Jammu towards paint for pleasing the condition. The opportunities in the paint industry are leveraging knowledge requirements and system in higher value zone and creating a positive impact towards retailers.

\section{REFERENCES}

1) Rowley J (1997), "Focusing on Customers", Library Review, Vol. 46, No. 2, pp. 81-89, MCB University, UK.

2) Priya Soni (2010) ,Customer perception and preferences towards branded products (with special reference to television sets) Indian Journal of Marketing Volume: 40 Number 2, pp.49-55

3) Raghavan, D. (2006), "Indian Coatings Industry: An Eye on the Future", Chemical Business, Vol. 20(6), pp. 87-89.

4) Pallavi Kumari (2012); Changing Purchase Behaviour Of Indian Customers, Arth Prabhand A Journal of Economics and Management, Vol.1 Issue 8

5) Akhilesh Chandra Pandey (2009), Study of Relationship between Brand Perception and Purchase Behavior of Consumer: A Case of Paint Industry, Pragyaan : JOM" Volume 7 : Issue 1, June 